\title{
Occurrence of Type-1C Fimbriae on Escherichia coli Strains Isolated from Human Extraintestinal Infections
}

\author{
By AULI PERE, ${ }^{1}$ MAIJA LEINONEN, ${ }^{2}$ VUOKKO VÄISÄNEN-RHEN, \\ MIKAEL RHEN ${ }^{1}$ AND TIMOK. KORHONEN ${ }^{1 *}$ \\ Department of General Microbiology, University of Helsinki ${ }^{1}$, and National Public Health \\ Institute ${ }^{2}$, Mannerheimintie 172, SF-00280, Helsinki 28, Finland
}

(Received 10 December 1984)

\begin{abstract}
Two monoclonal antibodies specific for type-1C fimbriae of Escherichia coli were produced. In enzyme-linked immunosorbent assay and immunoblotting the antibodies, which were of the IgGl isotype, reacted with type-1C, but not with $\mathrm{P}$ or type-1 fimbriae of $E$. coli strain KS71. Immunoblotting and immunoprecipitation of crude fimbrial extracts from 25 strains invariably gave an apparent molecular weight of 17000 for the type- $1 \mathrm{C}$ fimbrillin. A total of $313 \mathrm{E}$. coli strains, isolated from patients with extraintestinal infection or from faeces of healthy children, were screened for the presence of type-1C fimbriae using both the monoclonal and polyclonal antibodies. Of these, $45(14 \%)$ strains had type-1C fimbriae, with the highest frequency $(27 \%)$ on strains isolated from patients with pyelonephritis. No faecal strain had type- $1 \mathrm{C}$ fimbriae, and the frequency on the other diagnostic groups ranged from 11 to $15 \%$. Thus, no direct correlation between type- $1 \mathrm{C}$ fimbriae and bacterial virulence in human extraintestinal infections was found. Type-1C fimbriae were detected on only a few $E$. coli serotypes, notably on all $\mathrm{O} 6: \mathrm{K} 2: \mathrm{Hl}$ and $\mathrm{O} 22: \mathrm{K} 13: \mathrm{H} 1$ strains tested.
\end{abstract}

\section{INTRODUCTION}

Enterobacterial fimbriae are filamentous surface proteins that serve as binding organelles (Duguid \& Old, 1980; Korhonen et al., 1980). In Escherichia coli, specific adhesion to host epithelium, as in human pyelonephritis (Svanborg Edén et al., 1976) and diarrhoea (Gaastra \& de Graaf, 1982), plays a significant role in bacterial pathogenicity.

The many types of fimbriae in $E$. coli are characterized by binding specificity, serological properties, serotype of the strains, and the associated clinical situation. Most $E$. coli strains possess mannose-binding type-1 fimbriae (Duguid \& Old, 1982); no specific association has been demonstrated between type-1 fimbriae and bacterial virulence in humans. Most $E$. coli strains associated with human pyelonephritis carry $P$ fimbriae (Väisänen-Rhen et al., 1984), which mediate bacterial adhesion to P-blood-group-specific glycosphingolipids on human uroepithelium (Korhonen et al., 1980, 1982; Leffler \& Svanborg Edén, 1980; Källenius et al., 1981). Many E. coli strains causing meningitis or sepsis in neonates carry $S$ fimbriae that bind to sialyl galactoside structures on human erythrocytes (Parkkinen et al., 1983; Korhonen et al., 1984,1985 ) and a few pathogenic strains possess $M$ fimbriae, which recognize the aminoterminal part of glycophorin $\mathrm{A}^{\mathrm{M}}$ (Väisänen et al., 1982). E. coli strains causing diarrhoea in humans and animals carry fimbriae (such as K88, K99 and colonization factor antigens) which mediate bacterial adhesion to the host intestine (Gaastra \& de Graaf, 1982). Pathogenic E. coli strains usually exhibit two or three fimbrial types (Väisänen-Rhen et al., 1984), which show fast phase variation and mostly occur on separate cells (Rhen et al., 1983d; Nowicki et al., 1984).

A fimbrial antigen termed type-1C (Ørskov et al., 1982) has been purified from three E. coli strains (Klemm et al., 1982; Rhen et al., 1983a,b). It is serologically distinct from other $E$. coli fimbriae but shares structural similarity with type-1 fimbriae. However, its binding properties have not been established, so its occurrence on $E$. coli strains and its biological function have 
remained unknown. As a first step in determining the biological function of the type-1C fimbria, we prepared monoclonal antibodies against it and tested its presence in 313 E. coli strains isolated from patients with extraintestinal infections and from faeces of healthy children.

\section{METHODS}

Bacteria. E. coli strain KS71 and its fimbriae have been described previously (Korhonen et al., 1982; Rhen et al., $1983 a, b, c, d$; Nowicki et al., 1984; Rhen, 1985). Of the 313 test strains, 239 were isolated from urine of girls with acute pyelonephritis $(n=67)$, cystitis $(n=60)$ or asymptomatic bacteriuria $(n=62)$ and from faeces of healthy children $(n=50)$. The strains have been characterized in detail (Väisänen et al., 1981; Väisänen-Rhen et al., 1984). Seven strains were isolated from urine of boys with pyelonephritis. The other 67 strains were isolated from cases of neonatal sepsis or meningitis and have been described by us recently (Korhonen et al., 1985). The strains were stored in nutrient agar stabs at room temperature and were subcultured on nutrient agar plates as described previously (Korhonen et al., 1982).

Fimbriae. KS7IABC fimbriae, purified from agar-grown cells, were those described previously (Korhonen $e t$ al., 1982). KS71 A, KS71 B, KS71C and KS71D (type-1) fimbriae were purified from recombinant strains having only one of the fimbrial genes (Rhen et al., 1983c; M. Rhen, unpublished observations).

Monoclonal antibodies. BALB/C mice were immunized with purified KS71ABC fimbriae by four successive intraperitoneal injections of $50 \mu \mathrm{g}$ over two weeks. A booster of $50 \mu \mathrm{g}$ was given one month later.

The method of cell fusion, which was done $3 \mathrm{~d}$ after the booster, was a slight modification of that described by Galfre et al. (1977). BALB/C myeloma cell line SP-2/O-Ag-14 (Flow Laboratories) was cultured in R-medium, which was RPMI 1640 medium buffered with sodium bicarbonate (Flow Laboratories) and supplemented with $17 \%$ (v/v) foetal calf serum (Flow Laboratories), $250 \mu \mathrm{g} \mathrm{L}(+)$-glutamine $\mathrm{ml}^{-1}$ (Fluka AG, Buchs, Switzerland), 100 IU G-Na-penicillin $\mathrm{ml}^{-1}$ (Hoechst AG, Frankfurt am Main, FRG), $100 \mathrm{IU}$ streptomycin sulphate $\mathrm{ml}^{-1}$ (Sigma) and $25 \mathrm{IU}$ nystatin or $30 \mu \mathrm{g}$ amphotericin $\mathrm{B} \mathrm{ml}^{-1}$ (E. R. Squibb \& Sons, Princeton, NJ, USA).

Spleen cells from two immunized mice and SP-2 cells of exponential growth phase were combined in a ratio of $10: 1$. After washing, cells were fused by adding, over a period of $1 \mathrm{~min}, 1 \mathrm{ml}$ prewarmed $\left(37^{\circ} \mathrm{C}\right) 50 \%(\mathrm{w} / \mathrm{v})$ PEG 1500 (Fluka AG) in RPMI 1640 medium. Over the next $4 \mathrm{~min}, 10 \mathrm{ml}$ prewarmed R-medium without foetal calf serum was added to the suspension. Cells were then sedimented by centrifugation ( $5 \mathrm{~min}, 400 \mathrm{~g}$ ), resuspended in $40 \mathrm{ml} \mathrm{R}$-medium, and distributed ( $100 \mu \mathrm{l}$ per well) in 96-well, flat-bottomed microtest plates (Nunc, Roskilde, Denmark). After overnight incubation, $100 \mu \mathrm{l}$ R-medium supplemented with hypoxanthine $(100 \mu \mathrm{M})$, thymidine $(16 \mu \mathrm{M})$ and aminopterin $(0.4 \mu \mathrm{M})$ (HAT; Littlefield, 1964; Flow Laboratories) and containing spleen cells from an unimmunized BALB/C mouse was added to each well. Positive hybridomas were identified by testing samples of culture supernatants in enzyme-linked immunosorbent assay with purified $\mathrm{KS} 71 \mathrm{ABC}$ fimbriae as antigens, and cloned by the limiting dilution in microtest plates containing BALB/C spleen cells as a feeder layer. Positive clones were expanded in R-medium, and culture supernatants were stored at $-20^{\circ} \mathrm{C}$. The hybrid cells were stored at $-70{ }^{\circ} \mathrm{C}$ or in liquid nitrogen in R-medium containing $7.5 \%(\mathrm{v} / \mathrm{v})$ dimethylsulphoxide (Merck) at a cell density of about $5 \times 10^{6} \mathrm{ml}^{-1}$

Enzyme-linked immunosorbent assay (ELISA). Monoclonal antibodies in diluted culture supernatants were screened for specificity by ELISA (Engvall \& Perlman, 1972) using purified fimbriae as antigens as previously described (Korhonen et al., 1982). Rabbit antiserum against purified type-1C fimbriae of strain KS71 was that previously described (Rhen et al., 1983a, $b, d$; Nowicki et al., 1984). Alkaline phosphatase-conjugated anti-rabbit and anti-mouse IgG were from Orion Diagnostica, Helsinki, Finland. Immunoglobulin isotypes of monoclonal antibodies were determined from diluted culture supernatants with the following class-specific rabbit anti-mouse immunoglobulins: anti-IgG1, anti-IgG2, anti-IgG2a, anti-IgG2b, anti-IgG3, anti-IgA and anti-IgM (Litton Bionetics, Charleston, USA). The level of antibody binding was detected with alkaline phosphatase-conjugated swine anti-rabbit IgG (Orion Diagnostica) and p-nitrophenyl phosphate (Sigma) as substrate.

Polyacrylamide gel electrophoresis and immunoblotting. Polyacrylamide gel electrophoresis in sodium dodecyl sulphate (SDS-PAGE) was done in $1.5 \mathrm{~mm}$-thick slab gels by the system of Laemmli (1970). A low-molecularweight electrophoresis calibration kit (Pharmacia) was used as a standard. Peptide bands were stained with Coomassie brilliant blue R250. Specificity of monoclonal antibodies was tested by immunoblotting. Fimbrial crude extracts (Korhonen et al., 1984) or purified fimbriae were subjected to SDS-PAGE, and subsequent electrophoretic transfer to nitrocellulose membranes and immunoblotting were essentially as described by Towbin et al. (1979). Peroxidase-conjugated rabbit anti-mouse immunoglobulins were from Dakopatts, Copenhagen, Denmark, and 4-chloro-1-naphthol, used in the colour reaction, was from Bio-Rad Laboratories.

Immunoprecipitation. Fimbrial crude extracts were obtained and precipitated with rabbit anti-type-1C fimbriae serum (Rhen et al., 1983a) as recently described (Korhonen et al., 1984).

Agglutination tests. Bacterial agglutination with antibodies was done as described by Rhen et al. (1983c). Rabbit antiserum was used in $10^{-2}$, and monoclonal antibodies in $10^{-1}$, dilutions. For negative control, agglutination tests were done in phosphate-buffered saline (PBS), pH 7.1, and in SP-2 culture supernatant. 


\section{RESULTS}

\section{Specificity of monoclonal antibodies}

Mice were immunized with fimbriae purified from E. coli KS71 grown on agar plates. On agar strain KS71 forms three fimbriae: two types of $\mathrm{P}$ fimbriae (termed $\mathrm{A}$ and $\mathrm{B}$ ) and type-1C (KS71C) fimbriae (Rhen et al., 1983a, b, c, d), hence the term KS71ABC fimbriae for the immunizing antigens. An SDS-PAGE analysis of KS71 ABC fimbriae is shown in Fig. 1(a), lane A. We obtained four hybridoma clones producing antibodies specific for type- $1 \mathrm{C}$ fimbriae. Two were chosen for further use; their reactions with strain KS71 fimbriae in ELISA are shown in Table 1. The hybridoma clones $\mathrm{F} 4 \mathrm{C} 1$ and $\mathrm{F} 4 \mathrm{C} 2$ were specific for type-1C fimbriae of strain KS71; no titres were observed with purified A, B or D (type-1) fimbriae of strain KS71. In contrast, the rabbit antiserum prepared against purified type- $1 \mathrm{C}$ fimbriae showed titres against KS71A, KS71B and KS71D fimbriae, which were less than $1 \%$ of the reaction with KS71C fimbriae.

Specificity of the monoclonal antibodies was also tested by immunoblotting. Fig. 1(b) shows immunoblotting of KS71 ABC fimbriae (lane A) and of purified KS71C fimbriae (lane B) with $\mathrm{F} 4 \mathrm{C} 1$; identical results were obtained with $\mathrm{F} 4 \mathrm{C} 2$. Both monoclonal antibodies reacted strongly with $\mathrm{KS} 71 \mathrm{C}$, but not with KS71A or KS71B, fimbriae. It was concluded that the clones $\mathrm{F} 4 \mathrm{C} 1$ and $\mathrm{F} 4 \mathrm{C} 2$ were specific for the KS71C fimbriae.

Isotype analysis by ELISA showed that both $\mathrm{F} 4 \mathrm{Cl}$ and $\mathrm{F} 4 \mathrm{C} 2$ were of the IgG1 isotype.

\section{Cross-reaction of $\mathrm{F} 4 \mathrm{Cl}$ with heterologous strains}

We used immunoblotting of crude fimbrial extracts to assay cross-reactions of the monoclonal antibody $\mathrm{F} 4 \mathrm{Cl}$ with type-1C fimbriae of strains other than KS71. Fig. 1(a) shows an SDSPAGE analysis of fimbrial extracts from eight $E$. coli strains that were agglutinated by rabbit anti-KS71C serum and by $\mathrm{F} 4 \mathrm{C} 1$ and $\mathrm{F} 4 \mathrm{C} 2$ (lanes $\mathrm{C}$ to $\mathrm{J}$ ), and from two strains not agglutinated by the antibodies (lanes $\mathrm{K}$ and $\mathrm{L}$ ). The positive strains represented major serotypes of type-1Cfimbriated strains (see below). Most strains possessed more than one fimbrial antigen, as shown by multiple peptide bands with apparent molecular weights of 17000 to 22000 . In each case, only a peptide with an apparent molecular weight of 17000 reacted with $\mathrm{F} 4 \mathrm{C} 1$ (Fig. 1 b).

\section{Occurrence of type-IC fimbriae on E. coli strains}

We then screened for the presence of type-1C fimbriae in $313 \mathrm{E}$. coli strains isolated from patients with extraintestinal infection or from faeces of healthy children. The assay consisted of bacterial agglutination by $\mathrm{F} 4 \mathrm{Cl}, \mathrm{F} 4 \mathrm{C} 2$ and polyclonal rabbit antiserum against $\mathrm{KS} 71 \mathrm{C}$ fimbriae. A strain was considered type-1C-positive if it was agglutinated by rabbit anti-KS71C serum and/or the monoclonal antibodies but not in PBS or by SP- 2 culture supernatant. In all, 45 strains were considered type-1C-positive. Of these, 44 were agglutinated by polyclonal serum and by the monoclonal antibodies. One strain was agglutinated by polyclonal serum only. Bacterial agglutinations were confirmed by SDS-PAGE analyses of immunoprecipitates obtained from fimbrial extracts with rabbit antiserum against KS71C fimbriae. This was done on 25 type-1C-positive and 46 type-1C-negative strains, including all strains showing a strong autoagglutination in PBS or SP-2 culture supernatant. Analysis of immunoprecipitates from positive strains showed a 17000 molecular weight peptide band, which was lacking in precipitates from strains considered to be type-1C-negative (not shown). The two methods thus gave identical results.

A total of $45(14 \%)$ of the strains possessed type-1C fimbriae (Table 2); $20(27 \%)$ of the strains from pyelonephritis, but none of the faecal strains, were type-1C-fimbriated. In the other diagnostic groups the frequency of type-1C fimbriae ranged from 11 to $15 \%$. Thus, no specific association was found between possession of type-1C fimbriae and bacterial virulence.

\section{Serotypes of the type-1C-fimbriated strains}

Serotypes of the strains used in this study have been described previously (Väisänen-Rhen $e t$ al., 1984; Korhonen et al., 1985). Type-1C-fimbriated strains belonged to seven $\mathrm{O}$ groups only: O6 (23 strains), O4 (five strains), O18 (five strains), O22 (five strains), O75 (two strains), O25 

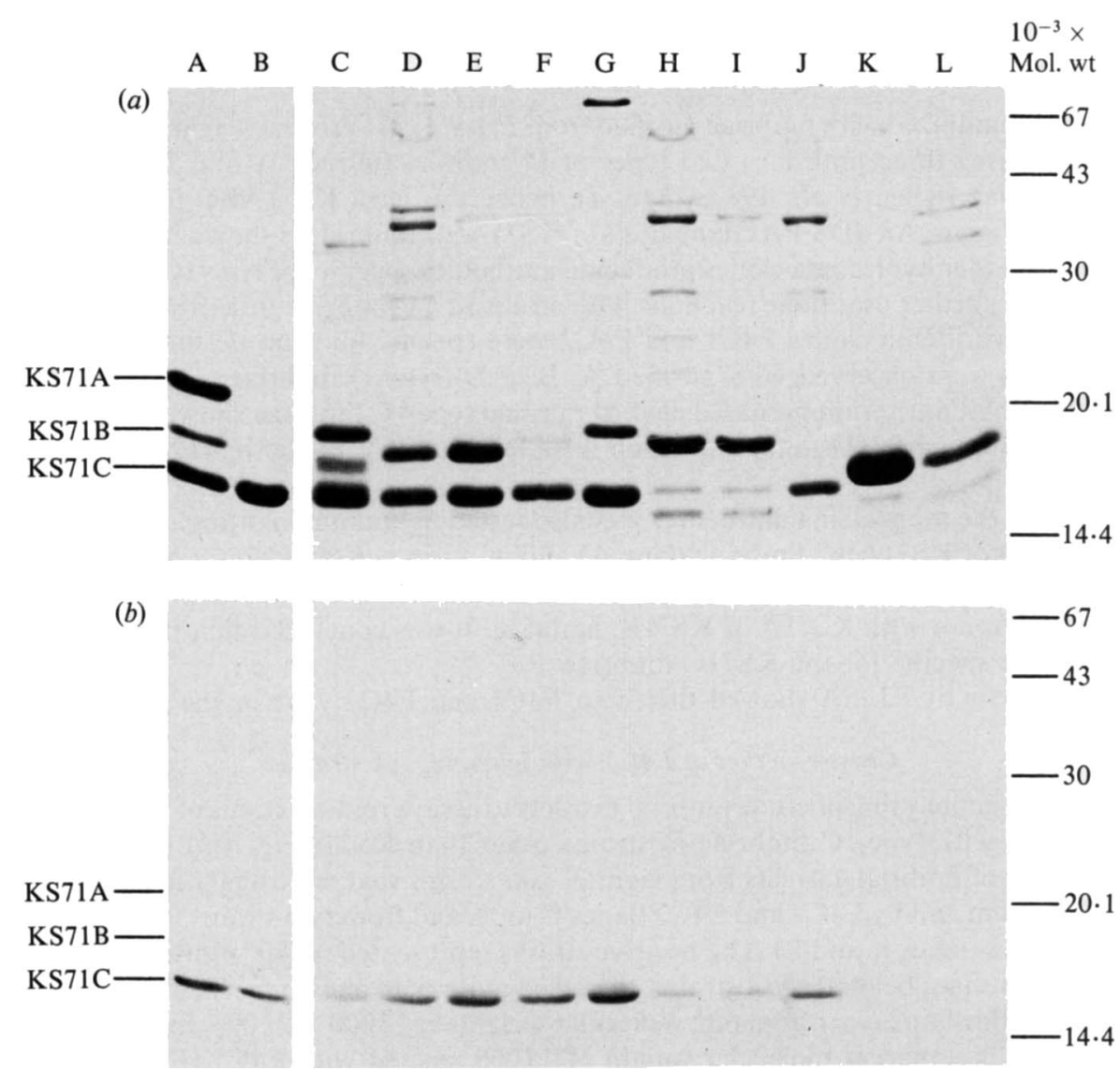

Fig. 1. (a) SDS-PAGE analysis of purified KS71ABC (lane A) and KS71C fimbriae (lane B) and of fimbrial extracts (lanes $C$ to $L$ ). Lanes $C$ to $J$ are extracts from strains agglutinated by $F 4 C 1$; lanes $K$ and $\mathrm{L}$ are from strains that were not agglutinated. Serotypes of the strains are: $\mathrm{O} 4: \mathrm{K} 12$ (lanes $\mathrm{A}$ and $\mathrm{B}$ ), $\mathrm{O} 4$ (lane C), O6:K2:HI (lanes D and E), O6:K 5:H- (lane F), O6:K5:H1 (lane G), O18:K5:H(lane H), O18 (lane I), O22 (lane J), O6 (lane K), and O18:K5:H7 (lane L). The migration distances of $\mathrm{KS} 71 \mathrm{~A}, \mathrm{KS} 71 \mathrm{~B}$ and $\mathrm{KS} 71 \mathrm{C}$ fimbrillins are indicated on the left, and the positions of standard proteins (kDal) on the right. (b) Immunoblotting of duplicate gels with $\mathrm{F} 4 \mathrm{C} 1$ monoclonal antibody.

(two strains), and $\mathrm{O} 2$ (one strain); two of the strains were rough. Full serotypes of the strains are given in Table 3. It should be noted that none of the $\mathrm{O} 1, \mathrm{O} 7, \mathrm{O} 8, \mathrm{O}, \mathrm{O} 16, \mathrm{O} 50, \mathrm{O} 77, \mathrm{O} 83, \mathrm{O} 85$, O86, O88, O119, or nontypable strains tested had type-1C fimbriae.

\section{DISCUSSION}

Type-1C fimbriae resemble other, non-type-1 fimbriae of $E$. coli in that they occur in only a few E. coli serotypes. All of the type-1C-fimbriated strains studied belonged to seven $\mathrm{O}$ groups $(\mathrm{O} 2, \mathrm{O} 4, \mathrm{O} 6, \mathrm{O} 18, \mathrm{O} 22, \mathrm{O} 25, \mathrm{O} 75)$, and two of the strains were rough (Table 3). The most frequent serotypes were $\mathrm{O} 6: \mathrm{K} 2: \mathrm{H} 1(25 \%$ of type-1C-fimbriated strains $)$ and $\mathrm{O} 22: \mathrm{K} 13: \mathrm{H} 1$ $(7 \%)$; in fact, all strains with these two serotypes in our material possessed type-1C fimbriae. Strains with serotype $\mathrm{O} 6: \mathrm{K} 2: \mathrm{H} 1$ are among the virulent clonal groups identified in $E$. coli strains from pyelonephritis (Väisänen-Rhen et al., 1984) and bacteremic sepsis (Korhonen $e t$ al., 1985); however, it is noteworthy that none of the other clones associated with virulence had type-1C fimbriae. Our results are in accordance with those of Ørskov et al. (1982), who found type-1C fimbriae on urinary isolates with serotypes $\mathrm{O} 4, \mathrm{O}, \mathrm{O} 18, \mathrm{O} 23, \mathrm{O} 75, \mathrm{O} 78$ and $\mathrm{O} 83$. 
Table 1. Serological reactions of the monoclonal antibodies with fimbriae from E. coli KS71

Antibody titre, as tested by ELISA, is given as the logarithm of the reciprocal of the highest dilution of hybridoma culture supernatant or antiserum giving an absorbance (at $405 \mathrm{~nm}$ ) four times higher than that given by SP-2 culture supernatant. Rabbit preimmune serum gave titres of $<2$ for all fimbriae. The results are means of duplicate determinations with variation of \pm 0.2 or less. For the monoclonal antibodies, titres of supernatants of different days varied by $\pm 0 \cdot 3$.

Antibody titre to strain KS71 fimbriae

\section{Antibody}

$\mathrm{F} 4 \mathrm{Cl}$

$\mathrm{F} 4 \mathrm{C} 2$

Polyclonal anti-KS71C serum

\begin{tabular}{crrcr}
\multicolumn{5}{c}{ Antibody titre to strain KS71 fimbriae } \\
$\overbrace{\text { KS71ABC }}^{\text {KS71A }}$ & KS71B & KS71C & KS71D \\
4.0 & $<2.0$ & $<2.0$ & 5.2 & $<2.0$ \\
3.8 & $<2.0$ & $<2.0$ & 4.9 & $<2.0$ \\
3.9 & 2.3 & 2.0 & 4.9 & 2.1
\end{tabular}

Table 2. Occurrence of type- $I C$ fimbriae on E. coli strains

\begin{tabular}{lcc}
\multicolumn{1}{c}{ Diagnostic group } & $\begin{array}{c}\text { No. of } \\
\text { strains } \\
\text { tested }\end{array}$ & $\begin{array}{c}\text { No. of } \\
\text { type-1C-fimbriated } \\
\text { strains* }\end{array}$ \\
Pyelonephritis & 74 & $20(27)$ \\
Cystitis & 60 & $8(13)$ \\
Asymptomatic bacteriuria & 62 & $7(11)$ \\
Bacteremic sepsis and meningitis & 67 & $10(15)$ \\
Faecal & 50 & $0(0)$ \\
Total & 313 & $45(14)$
\end{tabular}

* Percentage given in parentheses.

Table 3. Serotypes of the type-1C-fimbriated strains of E. coli

\begin{tabular}{|c|c|}
\hline Serotype & $\begin{array}{c}\text { No. of } \\
\text { type-1C-fimbriated } \\
\text { strains }\end{array}$ \\
\hline O6: K 2:H1 & 11 \\
\hline O6:K5:H1 & 5 \\
\hline O6:K $13: \mathrm{Hl}$ & 1 \\
\hline O6:K5:H- & 1 \\
\hline Other O6 & 5 \\
\hline $\mathrm{O} 4: \mathrm{K} 12: \mathrm{H} 5$ & 2 \\
\hline Other O4 & 3 \\
\hline $\mathrm{O} 18: \mathrm{K} 5: \mathrm{H}$ & 2 \\
\hline $\mathrm{O} 18: \mathrm{K} 12: \mathrm{H}_{-}$ & 1 \\
\hline Other O18 & 2 \\
\hline $\mathrm{O} 22: \mathrm{K} 13: \mathrm{H} 1$ & 3 \\
\hline Other O22 & 2 \\
\hline $\mathrm{O} 75: \mathrm{K} 5: \mathrm{H} 5$ & 1 \\
\hline O75:K95:H- & 1 \\
\hline $\mathrm{O} 25: \mathrm{K} 5: \mathrm{HI}$ & 2 \\
\hline $\mathbf{R}: \mathbf{K} 5: \mathrm{Hl}$ & 1 \\
\hline $\mathrm{R}: \mathrm{K} \mathbf{1}: \mathrm{H}_{-}$ & 1 \\
\hline $\mathrm{O} 2: \mathrm{K} 2$ & 1 \\
\hline Total & 45 \\
\hline
\end{tabular}

Similar associations between fimbriation and $E$. coli serotypes have been reported for $\mathrm{P}$ fimbriae (Väisänen-Rhen et al., 1984), S fimbriae (Korhonen et al., 1984) and for fimbrial antigens associated with enterotoxigenic strains (Gaastra \& de Graaf, 1982). The reason for these associations is not known, but they probably result from a common clonal evolution of strains with certain antigenic characters (Achtman et al., 1983). 
Type-1C fimbriae have been purified from three E. coli strains: C1023 (an O83:K24:H31 strain; Klemm et al., 1982), KS71 and ER2 (O4:K12 strains; Rhen et al., 1983a,b). The three fimbrillins have marked chemical similarities: an apparent molecular weight of 17000 and almost identical amino acid compositions and amino-terminal amino acid sequences. Interestingly, their chemical properties are similar to those of mannose-binding type-1 fimbriae (Salit \& Gotschlich, 1977; Hermodson et al., 1978). The apparent molecular weight of 17000 that was found for all type-1C fimbrillins by immunoblotting with monoclonal antibodies (Fig. 1) or by immunoprecipitation with a polyclonal serum (not shown) suggests that type-1C fimbriae on different $E$. coli strains have a rather conserved chemical structure. In this respect they resemble $\mathrm{S}$ fimbriae of $E$. coli (Korhonen et al., 1984) but differ from $\mathrm{P}$ fimbriae, which show marked heterogeneity in the apparent molecular weight of their subunits (Korhonen et al., 1982; Rhen et al., 1983b, d; A. Pere, V. Väisänen-Rhen, M. Rhen, J. Tenhunen \& T. K. Korhonen, unpublished results). Moreover, many E. coli strains possess two variants of $\mathrm{P}$ fimbriae (Rhen et al., 1983d; A. Pere, V. Väisänen-Rhen, M. Rhen, J. Tenhunen \& T. K. Korhonen, unpublished results); this was not observed for type-1C fimbriae (Fig. $1 b$ ).

The two monoclonal IgGl antibodies were specific for type-1C fimbriae of $E$. coli $\mathrm{KS} 71$, as assayed by ELISA (Table 1) and immunoblotting (Fig. 1). The fact that these monoclonal antibodies agglutinated all but one of the strains agglutinated by polyclonal anti-KS71C serum points to a strong conserved immunodeterminant on this fimbrial protein. However, type- $1 \mathrm{C}$ fimbriae from different strains show variations in serological cross-reactivity with other $E$. coli fimbriae. Type-1C fimbriae of strain ER2 cross-react with $P$ fimbriae of the same strain both in ELISA and in immunoprecipitation (Rhen et al., 1983b); the latter indicates a strong degree of cross-reactivity. Polyclonal anti-KS71C serum shows a weak reaction with KS71A, KS71B and KS71D fimbriae and with type-1 fimbriae of strain 2131 (Table 1; Rhen et al., 1983 b); these cross-reactions do not result in immunoprecipitation (Rhen et al., 1983a, $b, d$; Rhen, 1985). In the present study, a P-fimbrial protein with an apparent molecular weight of 19500 was coprecipitated with type-1C fimbriae from a few 06 and 018 strains by the polyclonal antiKS71C serum (not shown). It thus seems that, in addition to conserved antigenic determinants, type-1C fimbriae have weaker determinants occurring on certain $\mathrm{P}$ fimbriae. The properties of these P fimbriae will be described in a separate report (A. Pere, V. Väisänen-Rhen, M. Rhen, J. Tenhunen \& T. K. Korhonen, unpublished results). These examples illustrate the serological complexity of $E$. coli fimbriae.

Type-IC fimbriae did not seem to be associated with virulence in human extraintestinal infections caused by $E$. coli. They were most frequent among strains from pyelonephritis and absent from faecal ones (Table 2). However, the low percentages indicate that type-1C fimbriae are not directly involved in bacterial virulence in these infections; their frequency on $E$. coli strains that cause intestinal infections is unknown. Most of the type-1C-fimbriated strains described here have factors known to contribute to bacterial virulence in pyelonephritis: $78 \%$ of them are haemolytic and $67 \% \mathrm{P}$-fimbriated (Väisänen-Rhen et al., 1984; Korhonen et al., 1985). The association of type- $1 \mathrm{C}$ fimbriae with these virulence factors may merely reflect common clonal evolution (Achtman et al., 1983), or type-1C fimbriae may enhance virulence via mechanisms such as phase variation (Rhen et al., 1983d; Nowicki et al., 1984) which is thought to help bacteria avoid host immune responses. Fimbria-specific monoclonal antibodies should be useful tools for studying fimbrial phase variation.

This work was supported by the Academy of Finland and by the Yrjö Jahnsson Foundation. We thank Tuula Taskinen and Raili Kalliokoski for technical assistance.

\section{REFERENCES}

Achtman, M., Mercer, A., Kusecek, B., Pohl, A., Heuzenroeder, M., Aaronson, W., Sutton, A. \& SILVER, R. P. (1983). Six widespread bacterial clones among Escherichia coli $\mathrm{K} 1$ isolates. Infection and Immunity 39, 315-335.
Duguid, J. P. \& Old, D. C. (1980). Adhesive properties of Enterobacteriaceae. In Bacterial Adherence. Receptors and Recognition, series B, vol. 6, pp. 185-217. Edited by E. H. Beachey. London: Chapman \& Hall. 
Engvall, E. \& Perlman, P. (1972). Enzyme-linked immunosorbent assay, ELISA. III. Quantitation of specific antibodies by enzyme-labelled antiimmunoglobulin in antigen-coated tubes. Journal of Immunology 109, 129-135.

GaAstra, W. \& DE GRAaF, F. K. (1982). Host-specific fimbrial adhesins of noninvasive enterotoxigenic Escherichia coli strains. Microbiological Reviews 46, 129-161.

Galfre, G., Howe, S. C., Milstein, C., Butcher, G. W. \& Howard, J. C. (1977). Antibodies to major histocompatibility antigens produced by hybrid cell lines. Nature, London 266, 550-552.

Hermodson, M. A., Chen, K. C. S. \& Buchanan, T. M. (1978). Neisseria pili proteins: amino-terminal sequence and identification of an unusual amino acid. Biochemistry 17, 442-445.

Källenius, G., Svenson, S. B., Mölby, R., CederGReN, B., Hultberg, H. \& Windberg, J. (1981). Structure of carbohydrate part of receptor on human uroepithelial cells for pyelonephritogenic Escherichia coli. Lancet ii, 604-606.

Klemm, P., ØRSKOV, I. \& ØRSKOV, F. (1982). F7 and type 1-like fimbriae from three Escherichia coli strains isolated from urinary tract infections: protein chemical and immunological aspects. Infection and Immunity 36, 462-468.

Korhonen, T. K., EdÉn, S. \& Svanborg EdÉn, C. (1980). Binding of purified Escherichia coli pili to human urinary tract epithelial cells. FEMS Microbiology Letters 7, 237-240.

Korhonen, T. K., Väisänen, V., Saxen, H., HultBerG, H. \& Svenson, S. B. (1982). P-antigenrecognizing fimbriae from human uropathogenic Escherichia coli strains. Infection and Immunity 37, 286-291.

KorhONEN, T. K., VÄISÄNEN-RHEN, V., RHEN, M., Pere, A., ParkKinen, J. \& Finne, J. (1984). Escherichia coli fimbriae recognizing sialyl galactosides. Journal of Bacteriology 159, 762-766.

Korhonen, T. K., Valtonen, M. V., ParkKinen, J., VÄISÄNEN-RHEN, V., FINNE, J., ØRSKOV, F., ØrSKov, I., SVENSON, S. B. \& MÄKELÄ, P. H. (1985). Serotypes, hemolysin production and receptor recognition of Escherichia coli strains associated with neonatal sepsis and meningitis. Infection and Immunity 48, (in the Press).

LAEMMLI, U. K. (1970). Cleavage of structural proteins during assembly of the head of bacteriophage T4. Nature, London 227, 680-685.

Leffler, H. \& Svanborg EdÉN, C. (1980). Chemical identification of a glycosphingolipid receptor for Escherichia coli attaching to human urinary tract epithelial cells and agglutinating human erythrocytes. FEMS Microbiology Letters 8, 127-134.

LITTLEFIELD, J. W. (1964). Selection of hybrids from matings of fibroblasts in vitro and their presumed recombinants. Science $145,709-710$.

NowiCKI, B., RHEN, M., VÄISÄNEN-RHEN, V., PERE, A. \& KORHONEN, T. K. (1984). Immunofluorescence study of fimbrial phase variation in Escherichia coli KS71. Journal of Bacteriology 160, 691-695.

ØrSKov, I., ØRSKOV, F., BIRCH-ANDERSEN, A., Klemm, P. \& Svanborg EdÉn, C. (1982). Protein attachment factors: fimbriae in adhering Escherichia colistrains. In Seminars in Infectious Diseases. Volume IV. Bacterial Vaccines, pp. 97-103. Edited by J. B. Robbins, J. C. Hill \& J. C. Sadoff. New York: Thieme-Stratton.

Park Kinen, J., Finne, J., Achtman, M., Väisänen, V. \& KORHONEN, T. K. (1983). Escherichia coli strains binding neuraminyl $\alpha 2-3$ galactosides. Biochemical and Biophysical Research Communications 111, 456461 .

RHEN, M. (1985). Characterization of DNA fragments encoding fimbriae of the uropathogenic Escherichia coli strain KS71. Journal of General Microbiology 131, 571-580.

Rhen, M., Wahlström, E. \& Korhonen, T. K. (1983a). P-fimbriae of Escherichia coli: fractionation by immune precipitation. FEMS Microbiology Letters 18, 227-232.

Rhen, M., Klemm, P., Wahlström, E., Svenson, S. B., Källenius, G. \& KORHONEN, T. K. (1983b). P-fimbriae of Escherichia coli: immuno- and proteinchemical characterization of fimbriae from two pyelonephritogenic strains. FEMS Microbiology Letters 18, 233-238.

Rhen, M., Knowles, J., Penttilä, M. E., Sarvas, M. \& KORHONEN, T. K. (1983c). P-fimbriae of Escherichia coli: molecular cloning of DNA fragments containing the structural genes. FEMS Microbiology Letters 19, 119-123.

Rhen, M., MÄKelÄ, P. H. \& Korhonen, T. K. (1983d). P-fimbriae of Escherichia coli are subject to phase variation. FEMS Microbiology Letters 19, 267-271.

Salit, I. E. \& Gotschlich, E. C. (1977). Hemagglutination by purified type 1 Escherichia coli pili. Journal of Experimental Medicine 146, 1169-1181.

Svanborg EdÉn, C., Hanson, L. A., Jodal, U., LindBerg, U. \& SOHL-Åkerlund, A. (1976). Variable adhesion to normal urinary tract epithelial cells of Escherichia coli strains associated with various forms of urinary tract infection. Lancet ii, 490-492.

Towbin, H., Staehelin, T. \& Gordon, J. (1979). Electrophoretic transfer of proteins from polyacrylamide gels to nitrosellulose sheets: procedure and some applications. Proceedings of the National Academy of Sciences of the United States of America 76, 4350-4354.

Väisänen, V., Elo, J., Tallgren, L. G., Sittonen, A., Mäkelä, P. H., SVANborg EdÉN, C., Källenius, G., Svenson, S. B., Hultberg, H. \& Korhonen, T. K. (1981). Mannose-resistant haemagglutination and $P$ antigen recognition are characteristic of Escherichia coli causing primary pyelonephritis. Lancet ii, 1366-1369.

VÄISÄNEN, V., KORHONEN, T. K., JOKINEN, M., Gahmberg, G. C. \& Ehnholm, C. (1982). Blood group $M$ specific hemagglutinin in pyelonephritogenic Escherichia coli. Lancet i, 1192.

VÄISÄNEN-RhEN, V., ELO, J., VÄISÄNEN, E., SIITONEN, A., ØrSKov, I., ØRSKov, F., SVENSON, S. B., MÄKelä, P. H. \& Korhonen, T. K. (1984). Pfimbriated clones among uropathogenic Escherichia coli strains. Infection and Immunity 43, 149-155. 